\title{
EFEKTIVITAS MANIPULASI EFFLEURAGE TERHADAP TINGKAT DEPRESI, KECEMASAN DAN STRES PADA LANSIA
}

\author{
Muhammad Nurul Anwar ${ }^{1}$, Cerika Rismayanthi ${ }^{1}$ \\ ${ }^{1}$ Fakultas Ilmu Keolahragaan, Universitas Negeri Yogyakarta, J1. Colombo No. 1, Karangmalang Depok, \\ Sleman, Yogyakarta, Indonesia \\ muhammad.nurul@student.uny.ac.id, cerika@uny.ac.id
}

\begin{abstract}
Abstrak
Penelitian ini dilatar belakangi oleh pola pikir berlebih dan perasaan cemas pada lansia semakin naik ketika mengalami kelelahan akibat aktivitas sehari-hari.Penelitian ini bertujuan untuk mengetahui pengaruh efektivitas manipulasi effleurage terhadap tingkat depresi, kecemasan dan stres pada lansia di Yogyakarta. Penelitian ini merupakan penelitian deskriptif. Metode yang digunakan adalah Preexperimental design dengan pendekatan One-Shoot Case Study. Populasi penelitian ini adalah seluruh lansia laki-laki yang mengikuti perkumpulan di komplek Masjid Al Muhtadin dusun Plumbon, Banguntapan, Bantul. Sampel penelitian ini adalah lansia laki-laki di perkumpulan komplek Masjid Al Muhtadin terdapat 15 orang. Teknik pengambilan sampel dengan purposive sampling. Instrumen yang digunakan adalah angket. Teknik analisis yang dilakukan adalah deskriptif statistik frekuensi dalam bentuk persentase. Hasil penelitian ini menunjukkan bahwa manipulasi effleurage efektif terhadap tingkat depresi, kecemasan dan stres pada lansia di Yogyakarta. Tingkat efektivitas manipulasi effleurage terhadap tingkat depresi pada lansia yang berkategori normal 10 orang atau $66,67 \%$, dan ringan 5 orang atau 33,33\%. Efektif untuk tingkat kecemasan berkategori normal 13 orang atau 86,67\%, dan parah 2 orang atau 13,33\%. Sedangkan untuk tingkat stres yang berkategori normal 13 orang atau $86,67 \%$, dan ringan 2 orang atau13,33\%.
\end{abstract}

Kata Kunci: massage, effleurage, lansia.

\section{EFFECTIVENESS OF EFFLEURAGE MANIPULATION ON DEPRESSION, ANXIETY AND STRESS LEVELS IN THE ELDERLY}

\begin{abstract}
This research is motivated by excessive thought patterns and feelings of anxiety in the elderly increases when they experience fatigue due to daily activities. This study aims to determine the effect of the effectiveness of effleurage manipulation on the level of depression, anxiety and stress in the elderly in Yogyakarta. This research is a descriptive research. The method used is a pre-experimental design with a One-Shoot Case Study approach. The study population was all elderly men who participated in the gathering at the Al Muhtadin Mosque complex in Plumbon hamlet, Banguntapan, Bantul. The sample of this study is 15 elderly men in the Al Muhtadin Mosque complex. The sampling technique was purposive sampling. The instrument used was a questionnaire. The analysis technique used is descriptive frequency statistics in the form of percentages. The results of this study indicate that effleurage manipulation is effective against depression, anxiety and stress levels in the elderly in Yogyakarta. The effectiveness level of effleurage manipulation on the level of depression in the elderly is in the normal category of 10 people or $66.67 \%$, and mild 5 people or $33.33 \%$. Effective for the level of anxiety in the normal category of 13 people or $86.67 \%$, and severe 2 people or $13.33 \%$. Whereas for stress levels that are in the normal category of 13 people or $86.67 \%$, and mild 2 people or $13.33 \%$.

Keywords: massage, effleurage, elderly.
\end{abstract}




\section{PENDAHULUAN}

Lanjut usia adalah merupakan tahap akhir perkembangan pada kehidupan manusia, dengan terjadinya penurunan kondisi fisik atau biologis, kondisi psikologis, serta perubahan kondisi sosial. Sedangkan pasal 1 ayat (1), (3), (4) UU No. 13 tahun 1998 tentang kesehatan dikatakan bahwa lansia merupakan seseorang yang telah mencapai usia lebih dari 60 tahun. Pria dan wanita yang berusia enam puluh tahun ke atas atau yang biasanya disebut dengan lansia, adalah orang-orang beresiko untuk merasakan kesepian (Hurlock, 1997:54).

Statisik Penduduk Lanjut Usia tahun 2016 mengatakan bahwa negara Indonesia merupakan negara yang memiliki jumlah penduduk lansia terbesar ke empat di dunia setelah China, India, dan Amerika Serikat. Jumlah penduduk lansia di Indonesia mencapai 22,4 jiwa dengan 8,69 \% dari keseluruhan penduduk di Indonesia pada tahun 2016. Jumlah lansia perempuan lebih banyak dari pada jumlah lansia laki-laki, yaitu sebanyak 11,9 juta lansia perempuan dan 10,5 juta untuk lansia berjenis kelamin laki-laki.

Daerah Istimewa Yogyakarta memperoleh presentasi tertinggi dengan jumlah penduduk lansia sebanyak 13,05 \% dari total penduduk lansia di Indonesia. Lansia merupakan tahap lanjut dari proses kehidupan yang ditandai dengan menurunnya kemampuan tubuh untuk beradaptasi dengan lingkungan disekitarnya. Masa lansia merupakan tahap akhir dalam siklus perkembangan manusia di masa proses penuaan yang dialami oleh lansia dapat menyebabkan. Hilangnya kemampuan organ dan jaringan untuk memperbaiki diri secara perlahan-lahan dan semakin besarnya tekanan batin dan perasaan yang dialami. World Health Organitation (WHO), mengartikan lansia adalah seorang yang telah memasuki usia 60 tahun keatas. Lansia merupakan kelompok umur pada manusia yang telah memasuki tahapan akhir dari fase kehidupannya.

Penurunan fungsi kinerja organ dan bagian tubuh vital dari lansia menjadi tanda yang sangat mencolok pada masa lansia ini. Perubahan dari kemampuan mampu melakukan kegiatan dan aktivitas berat menjadi hanya dapat melakukan kegiatan yang memiliki tingkat intensitas dan frekuensi yang ringan. Adanya harapan hidup yang lebih baik tersebut memberikan semangat pada lansia untuk tetap dapat beraktivitas sebaik mungkin. Tingkat aktivitas yang dilakukan oleh lansia kebanyakan merupakan aktivitas fisik ringan tetapi tetap dapat mendorong dan mempertahankan kemampuannya secara baik. World Health Organisation (WHO) menetapkan 65 tahun sebagai usia yang menunjukkan proses menua yang berlangsung secara nyata dan seseorang telah disebut lansia. Lansia banyak menghadapi masalah kesehatan yang perlu penanganan segera dan terintregasi.

Proses penuaan dan penurunan fungsi organ vital menjadi hal yang sangat penting untuk tetap diberikannya penjagaan untuk dapat tetap memiliki tingkat kebugaran yang maksimal pada tingkat masa usia lanjut tersebut. Menurunnya metabolisme tubuh seseorang merupakan sesuatu yang pasti terjadi. Hanya saja, cepat atau lambatnya penurunan itu sangat bergantung pada kebiasaan hidup seseorang. Penurunan system metabolisme tubuh seseorang itu umumnya dimulai saat berusia 50 tahun. Menurunnya fungsi organ tubuh tersebut tentunya akan sedikit merubah kinerja organ yang dilakukan oleh lansia. Selain kualitas hidup yang tetap baik seperti diharapkan oleh lansia sedikit terganggu. Keinginan untuk tetap tampil bugar dan sehat tentunya harus diimbangi oleh kualitas aktivitas fisik yang disesuaikan dengan usia dan tingkat kemampuan yang masih dapat dilakukan oleh lansia. Salah satu penurunan fungsi yang dialami oleh lansia adalah sistem kardiovaskuler atau pernafasan, dan sistem neuromuskuler yang berhubungan dengan fleksibilitas.

Pada lansia akan mengalami berbagai penurunan, yaitu kekuatan massa otot, menurunnya fungsi neuromuscular terutama pada persendian dan banyaknya mengeluh kelentukan yang berkurang karena kelelahan otot pada tubuh. Seiring dengan adanya penurunan kemampuan pada lansia sering munculnya perasaan cemas dan adanya pola pikir yang semakin dalam. 
Kelelahan dalam bekerja terkadang bisa dianggap sebagai tanda adanya sakit yang ada pada tubuh lansia.

Kelelahan pada lansia dapat sangat cepat dirasakan ketika setelah bekerja dengan intensitas sedang ke berat. Kelelahan yang dirasakan tersebut akan membawa suasana yang kurang menenangkan pada lansia. Kecenderungan untuk terjadi kecemasan, depresi dan stres pada lansia dapat muncul akibat perasaan yang berlebih akbiat dari rasa sakit atau gangguan pada organ tubuh dengan skala ringan sampai berat. Proses relaksasi dengan memberikan rangsangan pada lansia setelah lelah melakukan aktivitas keseharian dapat memberikan efek yang baik bagi tubuh lansia.

Pemberian rangsangan berupa massage tentunya akan membantu mengurangi ketegangan otot dan memberikan rangsangan yang baik pada tubuh yang kelelahan. Adanya rangsangan yang memberikan efek positif tersebut diharapkan dapat mengurangi perasaan cemas dan pola pikir berlebihan yang bisa berakibat stres pada lansia. Perasaan tenang yang setelah dilakukannya rangsangan massage tersebut akan membantu lansia untuk memiliki kepercayaan diri untuk terus beraktivitas tanpa merasakan khawatir. Selain itu dengan adanya rangsangan tersebut diharapkan lansia juga tidak berpikir yang macam-macam berkepanjangan sehingga dapat berpikir positif.

Dalam hal ini peneliti memilih memberikan rangsangan pada lansia berupa manipulasi effleurage untuk dapat membantu mengurangi ketegangan otot dan mengurangi rasa sakit yang dialami oleh lansia. Manipulasi merupakan cara pegangan atau grip dalam melakukan masase pada daerah tertentu dan untuk memberikan pengaruh tertentu pada tubuh. Priyonoadi (2011: 8). Manipulasi effleurage merupakan manipulasi pokok dalam sport masase. Manipulasi effleurage dilakukan dengan menggunakan seluruh permukaan telapak tangan dan jari-jari untuk menggosok bagian tubuh yang lebar dan tebal seperti paha dan daerah pinggang. Daerah yang sempit seperti sela-sela tulang rusuk dan daerah jari-jari kadang hanya menggunakan tapak tangan bahkan jari-jari dan ujung-ujungnya, (Priyonoadi, 2011: 8). Effleurage adalah gerakan pijat yang paling dasar dan sering digunakan sebagai gerakan yang menghubungkan oleh terapis dalam mempertahankan kontak pada pasien dengan transfer gerakan yang lembut dari satu gerakan atau ke area tubuh selanjutnya. Effleurage cocok digunakan pada setiap area tubuh yang biasanya akan dipijat (sambil menghindari setiap daerah yang tidak boleh dipijat/kontraindikasi).

Tujuan manipulasi effleurage adalah memperlancar peredaran darah, cairan getah bening dan apabila dilakukan dengan tekanan yang lembut akan memberikan efek penenangan. Menurut Priyonoadi (2011: 8) juga menjelaskan tujuan dari manipulasi effleurage yaitu untuk membantu melancarkan peredaran darah dan cairan getah bening (cairan limpha), yaitu membantu mengalirkan darah di pembuluh balik (darah veneus) agar cepat kembali ke jantung. Oleh karena itu gerakan effleurage dilakukan selalu menuju arah jantung yang merupakan pusat peredaran darah.

Stres yaitu tertekan atau sesuatu yang terasa menekan dalam diri seseorang. Perasaan tertekan ini disebabkan oleh banyak faktor yang berasal dari dalam dirinya mupun dari luar. Husdarta (2014: 70) ketegangan adalah segala sesuatu yang dirasakan mendesak dan menekan diri seseorang. Ditinjau dari macam reaksi mental dan emosional, Singer menjelaskan adanya dua gejala yang berhubungan dengan emosi yaitu; tidak adanya kesiapan dan penuh kesiapan. Tidak adanya kesiapan atau under readines, berhubungan dengan kurangya motivasi untuk berbuat, sedangkan penuh kesiapan, berhubungan dengan kuatnya motivasi untuk menang atau penampilan buruk, takut kalah dan sebagainya. Seperti halnya otot lansia mengalami ketegangan karena melakukan pekerjaan fisik maka lansia dapat mengalami ketegangan psikis yang disebut stress seperti ketegangan otot tidak dapat dielakkan dalam kehidupan manusia sehari-hari. Lansia tidak dapat menghindarkan ketegangan psikis atau stres. Beberapa 
ketegangan diperlukan dan beberapa ketegangan tidak diperlukan dalam penampilan dan melakukan tugas (Harsono, 1996: 50).

Gangguan dan penurunan fungsi kerja organ pada lansia sedikit banyak memberikan pengaruh terhadap stabilitas aktivitas kehidupan sehari-hari pada lansia. Selain gangguan pada kemampuan beraktivitas fisik pada sehai-hari. Proses menua juga mempengaruhi keadaan psikologis seseorang seperti perubahan emosi menjadi mudah tersinggung, depresi, rasa cemas yang dialami seseorang dalam merespon perubahan fisik yang teradi pada dirinya (Suardiman, 2011 dalam Untari dkk, 2014: 53). Perasaan cemas, depresi dan stres terjadi karena adanya tingkat emosional yang diwujudkan dalam rasa gelisah dan pola pikir yang mendalam dalam waktu yang lama. Nevid dalam Hartini et al., (2012: 78)

Pemberian rangsangan ini diberikan sesuai dengan kebutuhan lansia dengan kebutuhan relaksasi pada organ tubuh agar tidak memiliki perasaan cemas dan pikiran yang berkepanjangan. Berdasarkan observasi dan pengamatan oleh penulis yang dilakukan di lingkungan sekitaran jogja didapatkan data pasien lansia banyak mengalami gangguan psikologis dan terjadinya cedera maupun masalah kesehatan pada tubuhnya yang dikarenakan kegiatan sehari-hari.

\section{METODE}

Penelitian ini merupakan penelitian Pre-experimen design yang bertujuan untuk menghubungkan kualitas atau sebab-akibat. Desain yang digunakan dalam penelitian ini yaitu Pre-experimental design dengan pendekatan One - Shoot Case Study (Studi Kasus Satu Tembakan), yaitu dalam desain penelitian ini terdapat suatu kelompok diberi treatment (perlakuan). Populasi dalam penelitian ini adalah seluruh Lansia laki-laki yang mengikuti perkumpulan di komplek Masjid Al Mahtadin dusun Plumbon, Banguntapan, Bantul. Populasi yang terdapat di perkumpulan di komplek Masjid Al Mahtadin terdapat 80 orang. Sampel dalam penelitan ini sejumlah 15 orang. Teknik pengambilan sampel yang memenuhi kriteria penelitian. Kriteria yang digunakan dalam penelitian ini sebagai berikut:a. lansia yang berjenis kelamin laki-laki, b. lansia yang berusia 45-65 tahun (Depkes RI; 2009) c. lansia laki-laki yang mengikuti perkumpulan di masjid Al Muhtadin d. lansia yang mengalami gangguan kesehatan ringan, seperti: rematik, hipertensi, insomnia, dll, berdasarkan kriteria tersebut maka diperoleh responden yang memenuhi kriteria sebesar 15 orang.

Instrumen yang digunakan untuk mengukur tingkat depresi dalam penelitian ini menggunakan skala DASS (The Depression Anxiety Stres Scales) memiliki 42 item yang mencakup tiga skala self-report yang dirancang untuk mengukur keadaan emosional negatif dari depresi, kecemasan dan stres. Skala ini terdiri dari tiga sisi berisi 14 item, dibagi menjadi sub skala 2-5 item dengan konten serupa. Penelitian ini mengukur tingkat depresi sehingga menggunakan skala depresi yang menilai disforia, keputusasaan, devaluasi kehidupan, penghinaan diri sendiri, kurangnya minat/keterlibatan, anhedonia, dan inersia. Responden diminta menggunakan skala keparahan/frekuensi 4 poin untuk menilai sejauh mana mereka telah mengalami setiap keadaan selama seminggu terakhir.

Pengumpulan data akan dilakukan setelah dilakukan perlakuan massage, menggunakan metode survey dan pemberian rangsangan. Adapun mekanisme pengumpulan data yaitu diberikannya massage Effleurage kemudian dilakukan tes akhir berupa pengisian angket efektivitas massage pada hari berikutnya setelah diarahkannya efek dari perlakuan atau rangsangan.

\section{HASIL DAN PEMBAHASAN}

Hasil penelitian tentang efektivitas manipulasi effleurage terhadap tingkat depresi, kecemasan dan stres pada lansia di perkumpulan di komplek Masjid Al Muhtadin dusun 
Plumbon, Banguntapan, Bantul. Penelitian ini dilakukan pada Selasa, 30 September 2018 dengan responden sebanyak 15 orang

\section{Deskripsi hasil efektivitas manipulasi effleurage terhadap tingkat depresi}

Dari hasil analisis data penelitian yang dilakukan maka dapat dideskripsikan dalam bentuk tabel sebagai berikut:

Tabel 1. Deskripsi Statistik Efektivitas Manipulasi Effleurage terhadap Tingkat Depresi

\begin{tabular}{|l|l|}
\hline \multicolumn{1}{|c|}{ Statistik } & \multicolumn{1}{c|}{ Skor } \\
\hline Mean & 5,6000 \\
\hline Median & 4,0000 \\
\hline Mode & $1,00 \mathrm{a}$ \\
\hline Std. Deviation & 5,09622 \\
\hline Range & 25,971 \\
\hline Minimum &, 00 \\
\hline Maximum & 13,00 \\
\hline
\end{tabular}

Dari data di atas dapar dideskripsikan efektivitas manipulasi effleurage terhadap tingkat depresi pada Lansia di perkumpulan di Komplek Masjid Al Muhtadin dusun Plumbon, Banguntapan, Bantul dengan rerata sebesar 5,60, nilai tengah sebesar 4,00, nilai sering muncul sebesar 1,00 dan simpangan baku sebesar 5,09. Sedangkan skor tertinggi sebesar 13 dan skor terendah sebesar 0,00. Dari hasil tes maka dapat dikategorikan efektivitas manipulasi effleurage terhadap

Tabel 2. Kategorisasi Efektivitas Manipulasi Effleurage Terhadap Tingkat Depresi

\begin{tabular}{|c|c|c|c|l|}
\hline No & Interval & Frekuensi & Presentase (\%) & Kategori \\
\hline 1 & $0-9$ & 10 & 66,67 & Normal \\
\hline 2 & $10-13$ & 5 & 33,33 & Ringan \\
\hline 3 & $14-20$ & 0 & 0,00 & Sedang \\
\hline 4 & $21-27$ & 0 & 0,00 & Parah \\
\hline 5 & $28-42$ & 0 & 0,00 & Sangat Parah \\
\hline \multicolumn{2}{r|}{ Jumlah } & 15 & 100 & \\
\hline
\end{tabular}

Dari tabel di atas dapat diketahui bahwa tingkat efektivitas manipulasi effleurage terhadap tingkat depresi pada Lansia di perkumpulan di Komplek Masjid Al Muhtadin dusun Plumbon, Banguntapan, Bantul adalah baik dengan pertimbangan rerata sebesar 5,6. Tingkat efektivitas massage effleurage terhadap tingkat depresi pada Lansia di perkumpulan di Komplek Masjid Al Muhtadin dusun Plumbon, Banguntapan, Bantul yang berkategori normal 10 orang atau $66,67 \%$, ringan 5 orang atau $33,33 \%$, sedang 0 orang atau $0 \%$, parah 0 orang atau $0,00 \%$ dan sangat parah 0 orang atau $0,00 \%$.

\section{Deskripsi hasil efektivitas manipulasi effleurage terhadap tingkat kecemasan}

Dari data efektivitas manipulasi effleurage terhadap tingkat kecemasan pada Lansia di perkumpulan di Komplek Masjid Al Muhtadin dusun Plumbon, Banguntapan, Bantul terhadap tingkat kecemasan didapatkan rerata sebesar 5,26, nilai tengah sebesar 4,00, nilai sering muncul sebesar 2,00 dan simpangan baku sebesar 5,86. Sedangkan skor tertinggi sebesar 19 dan skor terendah sebesar 0,00 .

Dari hasil analisis data penelitian yang dilakukan maka dapat dideskripsikan dalam bentuk tabel sebagai berikut: 
MEDIKORA, Vol. XVIII No. 2 Oktober 2019 - 105

Muhammad Nurul Anwar, Cerika Rismayanthi

Tabel 3. Deskripsi Statistik Efektivitas Manipulasi Effleurage Terhadap Tingkat Kecemasan

\begin{tabular}{|l|l|}
\hline \multicolumn{1}{|c|}{ Statistik } & \multicolumn{1}{c|}{ Skor } \\
\hline Mean & 5,2667 \\
\hline Median & 4,0000 \\
\hline Mode & $2,00 \mathrm{a}$ \\
\hline Std. Deviation & 5,86109 \\
\hline Range & 34,352 \\
\hline Minimum &, 00 \\
\hline Maximum & 19,00 \\
\hline
\end{tabular}

Tabel 4. Kategorisasi Efektivitas Manipulasi Effleurage Terhadap Tingkat Kecemasan

\begin{tabular}{|r|c|c|c|l|}
\hline No & Interval & Frekuensi & Presentase (\%) & Kategori \\
\hline 1 & $0-7$ & 13 & 86,67 & Normal \\
\hline 2 & $8-9$ & 0 & 0,00 & Ringan \\
\hline 3 & $10-14$ & 0 & 0,00 & Sedang \\
\hline 4 & $15-19$ & 2 & 13,33 & Parah \\
\hline 5 & $20-42$ & 0 & 0,00 & Sangat Parah \\
\hline \multicolumn{2}{r|}{ Jumlah } & 15 & 100 & \\
\hline
\end{tabular}

Dari tabel di atas dapat diketahui bahwa tingkat efektivitas manipulasi effleurage terhadap tingkat kecemasan pada Lansia di perkumpulan di Komplek Masjid Al Muhtadin dusun Plumbon, Banguntapan, Bantul adalah baik dengan pertimbangan rerata sebesar 5,26. Tingkat efektivitas manipulasi effleurage terhadap tingkat kecemasan pada Lansia di perkumpulan di Komplek Masjid Al Muhtadin dusun Plumbon, Banguntapan, Bantul yang berkategori normal 13 orang atau $86,67 \%$, ringan 0 orang atau $0,00 \%$, sedang 0 orang atau $0 \%$, parah 2 orang atau $13,33 \%$ dan sangat parah 0 orang atau $0,00 \%$.

\section{Deskripsi hasil efektivitas manipulasi effleurage terhadap tingkat stres}

Dari hasil analisis data penelitian yang dilakukan maka dapat dideskripsikan dalam bentuk tabel sebagai berikut:

Tabel 5. Deskripsi Statistik Efektivitas Manipulasi Effleurage Terhadap Tingkat Stres

\begin{tabular}{|l|l|}
\hline \multicolumn{1}{|c|}{ Statistik } & \multicolumn{1}{c|}{ Skor } \\
\hline Mean & 9,8000 \\
\hline Median & 10,0000 \\
\hline Mode & 13,00 \\
\hline Std. Deviation & 4,49126 \\
\hline Range & 20,171 \\
\hline Minimum & 2,00 \\
\hline Maximum & 18,00 \\
\hline
\end{tabular}

Dari data di atas dapar dideskripsikan efektivitas manipulasi effleurage terhadap tingkat Stres pada Lansia di perkumpulan di Komplek Masjid Al Muhtadin dusun Plumbon, Banguntapan, Bantul terhadap dengan rerata sebesar 9,8, nilai tengah sebesar 10,00, nilai sering muncul sebesar 13,00 dan simpangan baku sebesar 4,49. Sedangkan skor tertinggi sebesar 18 dan skor terendah sebesar 2,00. 
MEDIKORA, Vol. XVIII No. 2 Oktober 2019 - 106

Muhammad Nurul Anwar, Cerika Rismayanthi

Tabel 6. Kategorisasi Efektivitas Manipulasi Effleurage Terhadap Tingkat Stres

\begin{tabular}{|c|c|c|c|l|}
\hline No & Interval & Frekuensi & Presentase (\%) & \multicolumn{1}{|c|}{ Kategori } \\
\hline 1 & $0-14$ & 13 & 86,67 & Normal \\
\hline 2 & $15-18$ & 2 & 13,33 & Ringan \\
\hline 3 & $19-25$ & 0 & 0,00 & Sedang \\
\hline 4 & $26-33$ & 0 & 0,00 & Parah \\
\hline 5 & $34-42$ & 0 & 0,00 & Sangat Parah \\
\hline \multicolumn{2}{|c|}{ Jumlah } & 15 & 100 & \\
\hline
\end{tabular}

Dari tabel di atas dapat diketahui bahwa tingkat efektivitas manipulasi effleurage terhadap tingkat Stres pada Lansia di perkumpulan di Komplek Masjid Al Muhtadin dusun Plumbon, Banguntapan, Bantul adalah baik dengan pertimbangan rerata sebesar 9,8. Tingkat efektivitas manipulasi effleurage terhadap tingkat Stres pada Lansia di perkumpulan di Komplek Masjid Al Muhtadin dusun Plumbon, Banguntapan, Bantul yang berkategori normal 13 orang atau $86,67 \%$, ringan 2 orang atau $13,33 \%$, sedang 0 orang atau $0 \%$, parah 0 orang atau $0,00 \%$ dan sangat parah 0 orang atau $0,00 \%$.

Dari deskripsi hasil penelitian yang dilakukan tentang tingkat efektivitas manipulasi effleurage terhadap tingkat depresi, kecemasan dan stres pada Lansia perkumpulan di Komplek Masjid Al Muhtadin dusun Plumbon, Banguntapan, Bantul bahwa tingkat efektivitas manipulasi effleurage terhadap tingkat depresi pada Lansia di dusun Plumbon, Banguntapan, Bantul adalah baik dengan pertimbangan rerata sebesar 5,6. Tingkat efektivitas manipulasi effleurage terhadap tingkat depresi pada Lansia di dusun Plumbon, Banguntapan, Bantul yang berkategori normal 10 orang atau $66,67 \%$, ringan 5 orang atau 33,33\%, sedang 0 orang atau $0 \%$, parah 0 orang atau $0,00 \%$ dan sangat parah 0 orang atau $0,00 \%$. Tingkat efektivitas manipulasi effleurage terhadap tingkat kecemasan pada Lansia di dusun Plumbon, Banguntapan, Bantul adalah baik dengan pertimbangan rerata sebesar 5,26. Tingkat efektivitas manipulasi effleurage terhadap tingkat kecemasan pada Lansia di dusun Plumbon, Banguntapan, Bantul yang berkategori normal 13 orang atau 86,67\%, 2 orang atau 13,33\% dan tingkat efektivitas manipulasi effleurage terhadap tingkat stres pada Lansia di dusun Plumbon, Banguntapan, Bantul adalah baik dengan pertimbangan rerata sebesar 9,8. Tingkat efektivitas manipulasi effleurage terhadap tingkat stres pada Lansia di dusun Plumbon, Banguntapan, Bantul yang berkategori normal 13 orang atau 86,67\%, ringan 2 orang atau 13,33\%.

Berdasarkan hasil penelitian tersebut bahwa tingkat depresi, kecemasan dan stres pada lansia setelah mendapat rangsangan manipulasi effleurage berada pada kategori normal. Hal ini menunjukkan bahwa pemberian perlakuan rangsangan manipulasi effleurage dapat memberikan kontribusi yang efektif terhadap pengontrolan tingkat depresi, kecemasan dan stres pada lansia. Keluhan yang dirasakan oleh lansia sebelum diberikan perlakuan massage menjadi perhatian tersendiri dikarenakan lansia mengalami hal yang kurang nyaman dirasakan pada tubuh lansia. Selain itu, dengan diadakannya perlakuan terhadap keluhan pada lansia berupa manipulasi effleurage memberikan harapan pada lansia terhadap penanganan keluhan. Hal ini dapat dilihat terhadap minat lansia untuk berkenan dilakukan manipulasi effleurage. Pemberian rangsangan ini tidak hanya bertujuan untuk mengurangi keluhan saja tetapi secara psikologi akan mengurangi depresi, kecemasan dan stres pada lansia.

\section{SIMPULAN}

Berdasarkan hasil penelitian dan pembahasan yang telah dipaparkan maka dapat diambil kesimpulan bahwa manipulasi effleurage efektif terhadap tingkat depresi, kecemasan dan stres pada lansia di Yogyakarta. Tingkat efektivitas manipulasi effleurage terhadap tingkat depresi pada Lansia yang berkategori normal 10 orang atau 66,67\%, ringan 5 orang atau 33,33\%. Tingkat efektivitas manipulasi effleurage terhadap tingkat kecemasan pada Lansia yang 
berkategori normal 13 orang atau 86,67\%, parah 2 orang atau 13,33\%. Sedangkan tingkat efektivitas manipulasi effleurage terhadap tingkat stres pada Lansia yang berkategori normal 13 orang atau $86,67 \%$, ringan 2 orang atau13,33\%.

\section{DAFTAR PUSTAKA}

Badan Pusat Statistik. (2015). Data Penduduk Kecamatan Nita Menurut Kelompok Umur dan Jenis Kelamin. Sikka: BPS

Hurlock, E. B. (1997). Psikologi Perkembangan Suatu Pendekatan Sepanjang Rentang Kehidupan. Alih Bahasa: Isti widayanti. Edisi Kelima. Jakarta: Erlangga

Hartini, N. 2012. Hubungan Antara Penerimaan Diri Dengan Kecemasan Menghadapi Dunia Kerja Pada Tunadaksa Di UPT Rehabilitasi Sosial Cacat Tubuh Pasuruan. Skripsi tidak dipublikasikan. Surabaya: Fakultas Psikologi Universitas Airlangga Surabaya

Harsono. (1998). Coaching dan Aspek-aspek Psikologis dalam Coaching Departemen Pendidikan dan Kebudayaan. Jakarta: Proyek Pengembangan Lembaga Pendidikan dan Kebudayaan

Husdarta, (2010). Psikologi Olahraga. Bandung: Penerbit Alfabeta

Priyonoadi, B. (2011). Sport Massage. Yogyakarta: Fakultas Ilmu Keolahragaan Universitas Negeri Yogyakarta

Untari, I, \& Rohmawati. (2014). Faktor-Faktor Yang Mempengaruhi Kecemasan Pada Usia Pertengahan Dalam Menghadapi Proses Menua (Aging Process). Jurnal Keperawatan 